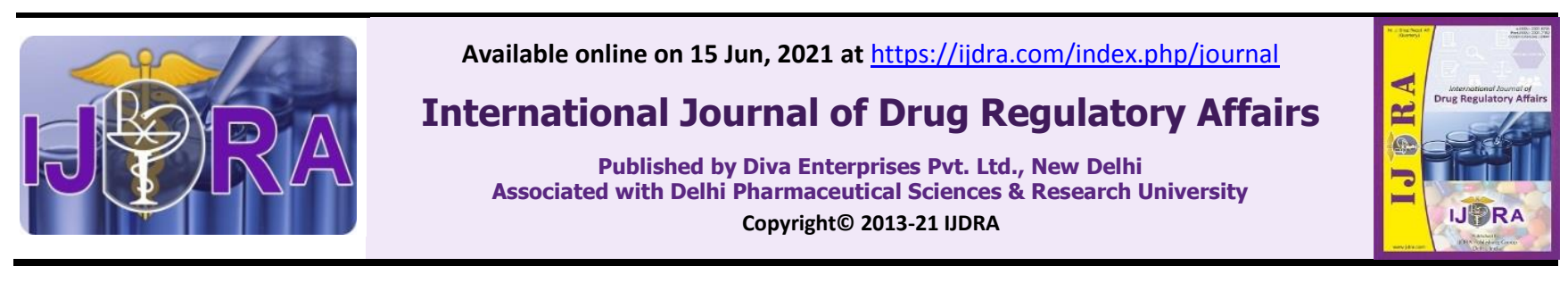

Review Article

OpenOAccess

\title{
Overview on Biopharmaceutics Classification System (BCS) based biowaiver requirements in African countries
}

\author{
Nidhi Sagar Pardeshi*, Iva Dhulia, Himani Patel, Umesh Dobariya, Sandip Sarvaiya \\ Department of Regulatory Affairs, Isazi Pharma and Techno Consultancy Private Limited, Vadodara, Gujarat, India - 390007
}

\begin{abstract}
Biopharmaceutics Classification System (BCS)-based biowaiver are meant to reduce the need for establishing in vivo bioequivalence in situations where in vitro data may be considered to provide a reasonable estimate of the relative in vivo performance of two products.

The BCS is a scientific approach designed to predict medicinal absorption based on the aqueous solubility and intestinal absorptive characteristics of the Pharmaceutical product. To ensure interchangeability, the multisource product must be therapeutically equivalent to the comparator product. Types of in vivo equivalence studies include comparative pharmacokinetic studies, comparative pharmacodynamic studies and comparative clinical studies.
\end{abstract}

This article briefly explains the BCS based biowaiver requirements in six major African countries i.e. Zimbabwe, South Africa, Uganda, Kenya, Botswana and Tanzania which facilitates regulatory medicine approval process when the dossier (application) is approved based on evidence of equivalence other than In vivo studies.

Keywords: BCS (Biopharmaceutics Classification System), MCAZ (Medicines Control Authority of Zimbabwe), MCC (Medicines Control Council), NDA (National Drug Authority), WHO (World Health Organization)

Article Info: Received 20 Apr. 2021; Review Completed 01 Jun. 2021; Accepted 02 Jun. 2021

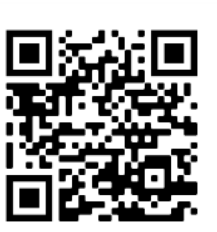

Cite this article as:

Pardeshi NS, Dhulia I, Patel H, Dobariya U, Sarvaiya S. Overview on Biopharmaceutics Classification System (BCS) based biowaiver requirements in African countries. Int J Drug Reg Affairs [Internet]. 2021 Jun 15 [cited 2021 Jun 15]; 9(2):26-29. Available from:

http://ijdra.com/index.php/journal/article/view/465

DOI: $10.22270 /$ ijdra.v9i2.465

*Corresponding author

\section{Introduction}

The multisource (generic) product development is usually characterization of the reference product design of pharmaceutically equivalent and bioequivalent product, multisource pharmaceutical products must conform to the same appropriate standards of quality, efficacy and safety as per the innovator's (comparator) product.

In-vivo equivalence studies include comparative pharmacokinetic studies, comparative pharmacodynamic studies and comparative clinical studies.

Conducting of therapeutic equivalence through a comparative clinical trial approach is not very practical because:

- Differences in formulation.

- Require a very large number of patients.

- The newer treatment might have more or serious side effects than standard treatment.
- Time taking and expensive process.

As described in aforementioned reasons the bioequivalence testing has been developed over the past years. The therapeutic equivalence can be assured when the multisource product is both pharmaceutically equivalent and bioequivalent Alternative approaches are described in this document may be acceptable provided, they are supported by adequate scientific justification.

A biowaiver means that in vivo bioavailability and/or bioequivalence studies may be waived. Instead of conducting expensive and time-consuming in vivo studies, a dissolution test could be adopted as the substitute basis for the decision as to whether the two pharmaceutical products are equivalent. However, the risk of therapeutic inequivalence of two immediate release products can never be reduced to zero, even if a full clinical study is performed. The conclusion of comparative clinical studies, in vivo bioequivalence studies, in vitro equivalence tests and biowaivers is based on statistics and scientific data. (1-3) 
Biopharmaceutics Classification System (BCS)-based biowaivers are meant to reduce the need for establishing in vivo bioequivalence in situations where in vitro data may be considered to provide a reasonable estimate of the relative in vivo performance of two products.

The BCS is a scientific approach designed to predict medicinal absorption based on the aqueous solubility and intestinal absorptive characteristics of the pharmaceutical product.

The BCS is classifying medicinal substances based on their aqueous solubility and intestinal permeability. The

\section{Oral drug products}

BCS

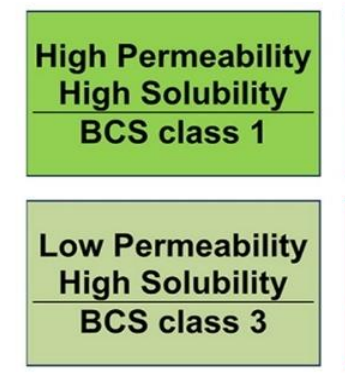

仓

Biowaiver

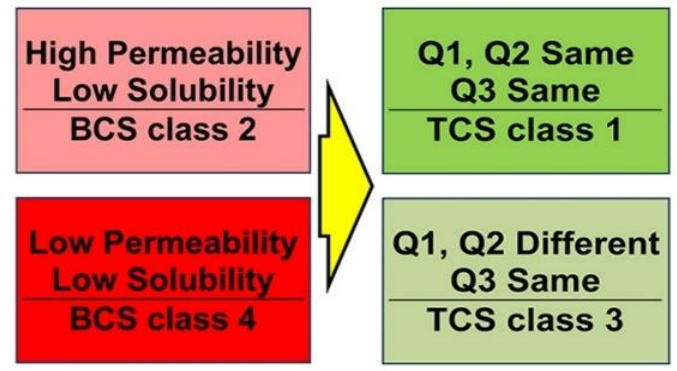

介 major factors which are basis of BCS classification for immediate release (IR) solid oral dosage forms:

- Excipient composition,

- Dissolution,

- Solubility

- Intestinal permeability.

The term biowaiver is applied to a regulatory drug approval process when the dossier (application) is approved based on evidence of equivalence other than in vivo equivalence testing. (1)

\section{Topical drug products}

TCS

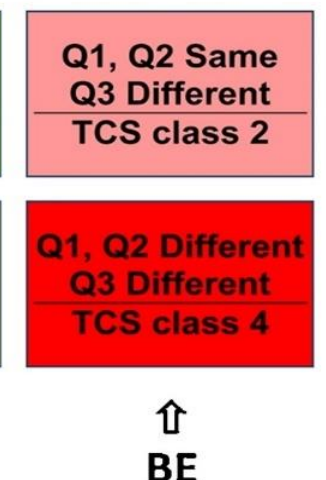

Figure 1. Biopharmaceutics Classification System (BCS) (4)

\section{Equivalence studies are not necessary in case as per WHO guideline}

Parenteral dosage (e.g. intravenously, subcutaneously or intramuscularly) as an aqueous solution containing the same API in the same molar concentration as the comparator product and the same or similar excipients in comparable concentrations to those in the comparator product)

- Oral solutions (e.g. syrups, elixirs and tinctures), contain the API in the same molar concentration as the comparator product, contain the same functional excipients in similar concentrations (if the API is BCS Class I) and the same excipients in similar concentrations (for APIs from other BCS classes);

- Powders for reconstitution as an aqueous solution and the resultant solution meets either criterion (1) or criterion (2) above;

- When pharmaceutically-equivalent products are gases.

- Otic or ophthalmic products prepared as aqueous solutions and contain the same API(s) in the same molar concentration and the same excipients in similar concentrations. Certain excipients (e.g. preservative, buffer, substance to adjust tonicity or thickening agent) may be different provided their use is not expected to affect bioavailability, safety and/or efficacy of the product;

- When pharmaceutically-equivalent products are topical products prepared as aqueous solutions and contain the same API(s) in the same molar concentration and the same excipients in similar concentrations (note that a waiver would not apply to other topical dosage forms like gels, emulsions or suspensions, but might be applicable to oily solutions if the vehicle composition is sufficiently similar).

- When pharmaceutically-equivalent products are aqueous solutions for nebulization or nasal drops, intended to be administered with essentially the same device, contain the same API(s) in the same concentration and contain the same excipients in similar concentrations (note that this waiver does not apply to other dosage forms like suspensions for nebulization, nasal drops where the API is in suspension, nasal sprays in solution or suspension, dry powder inhalers or pressurized metered dose inhalers in solution or suspensions). The pharmaceutical product may include different excipients provided their use is not expected to affect bioavailability, safety and/or efficacy of the product. (1)

\section{Equivalence studies necessity and types of study}

\section{In vivo studies}

For certain APIs and dosage forms, in vivo documentation of equivalence, through either a pharmacokinetic comparative bioavailability (bioequivalence) study, a comparative pharmacodynamic study or a comparative clinical trial is regarded as especially important. In vivo documentation of 
equivalence is necessary when there is a risk that possible differences in bioavailability may result in therapeutic inequivalence. (2) Examples are listed below.

- Oral, immediate-release pharmaceutical products with systemic action, except for the conditions outlined in section 10 ;

- Non-oral, non-parenteral pharmaceutical products designed to act systemically (such as transdermal patches, suppositories, nicotine chewing gum, testosterone gel and skin-inserted contraceptives);

- modified-release pharmaceutical products designed to act systemically, except for the conditions outlined in section 10;
- Fixed-dose combination (FDC) products with systemic action, where at least one of the APIs requires an in vivo study.

- Non-solution pharmaceutical products, which are for non-systemic use (e.g. for oral, nasal, ocular, dermal, rectal or vaginal application) and are intended to act without systemic absorption.

In the case of non-solution pharmaceutical products for non-systemic use, the equivalence is established through, e.g. Comparative clinical or pharmacodynamic studies, local availability studies and/or in vitro studies. In certain cases, measurement of the concentration of the API may still be required for safety reasons, i.e. in order to assess unintended systemic absorption. $(1,2)$

Below is summarized form of BCS based biowaiver requirements in 6 major African countries.

Table 1. Requirements for a BCS-based biowaiver study among 6 major African countries (2-9)

\begin{tabular}{|c|c|c|c|c|c|c|}
\hline Country & $\begin{array}{c}\text { Zimbabwe } \\
\text { (MCAZ) }\end{array}$ & $\begin{array}{l}\text { South Africa } \\
\text { (MCC) }\end{array}$ & Uganda & Kenya & Botswana & Tanzania \\
\hline API & $\begin{array}{l}\text { BCS Class I } \\
\& \text { III }\end{array}$ & $\begin{array}{l}\text { BCS Class I } \\
\& \text { III }\end{array}$ & $\begin{array}{l}\text { BCS Class } \\
\text { I \& III }\end{array}$ & $\begin{array}{l}\text { BCS Class I } \\
\& \text { III }\end{array}$ & BCS Class I \& III & $\begin{array}{l}\text { BCS Class I } \\
\& \text { III }\end{array}$ \\
\hline Excipients & $\begin{array}{l}\text { Qualitatively } \\
\text { and } \\
\text { Quantitatively } \\
\text { same }\end{array}$ & $\begin{array}{l}\text { Qualitatively } \\
\text { and } \\
\text { Quantitativel } \\
\text { y same }\end{array}$ & $\begin{array}{l}\text { Qualitative } \\
\text { ly and } \\
\text { Quantitativ } \\
\text { ely same }\end{array}$ & $\begin{array}{l}\text { Qualitatively } \\
\text { and } \\
\text { Quantitativel } \\
\text { y same }\end{array}$ & $\begin{array}{l}\text { Qualitatively and } \\
\text { Quantitatively } \\
\text { same }\end{array}$ & $\begin{array}{l}\text { Qualitatively } \\
\text { same and } \\
\text { Quantitativel } \\
\text { y similar }\end{array}$ \\
\hline Apparatus & $\begin{array}{l}\text { Paddle \& } \\
\text { Basket }\end{array}$ & $\begin{array}{l}\text { Paddle \& } \\
\text { Basket }\end{array}$ & $\begin{array}{l}\text { Paddle \& } \\
\text { Basket }\end{array}$ & $\begin{array}{l}\text { Not } \\
\text { specified* }\end{array}$ & Paddle \& Basket & $\begin{array}{l}\text { Paddle \& } \\
\text { Basket }\end{array}$ \\
\hline Agitation & $\begin{array}{l}75 \mathrm{rpm} \\
\text { (Paddle) } \\
100 \mathrm{rpm} \\
\text { (Basket) }\end{array}$ & $\begin{array}{l}75 \mathrm{rpm} \\
\text { (Paddle) } \\
100 \mathrm{rpm} \\
\text { (Basket) }\end{array}$ & $\begin{array}{l}50 \mathrm{rpm} \\
\text { (Paddle) } \\
100 \mathrm{rpm} \\
\text { (Basket) }\end{array}$ & $\begin{array}{l}\text { Not } \\
\text { specified* }\end{array}$ & $\begin{array}{l}50 \text { or } 75 \text { rpm } \\
\text { (Paddle) } \\
100 \mathrm{rpm} \text { (Basket) }\end{array}$ & $\begin{array}{l}50 \mathrm{rpm} \\
\text { (Paddle) } \\
100 \mathrm{rpm} \\
\text { (Basket) }\end{array}$ \\
\hline Buffer & $\begin{array}{l}\mathrm{pH} 1.2, \mathrm{pH} \\
4.5 \text { and } \mathrm{pH} \\
6.8\end{array}$ & $\begin{array}{l}\mathrm{pH} 1.2, \mathrm{pH} \\
4.5, \mathrm{pH} 6.8 \& \\
\text { QC media }\end{array}$ & $\begin{array}{l}\mathrm{pH} 1.2, \mathrm{pH} \\
4.5 \text { and } \mathrm{pH} \\
6.8\end{array}$ & $\begin{array}{l}\mathrm{pH} 1.2, \mathrm{pH} \\
4.5, \mathrm{pH} 6.8 \\
\& \text { QC media }\end{array}$ & $\begin{array}{l}\text { Buffer: pH } 1.0- \\
1.2 \text { (usually } 0.1 \mathrm{~N} \\
\mathrm{HCl} \text { or SGF } \\
\text { without enzymes), } \\
\mathrm{pH} 4.5 \text {, and pH } \\
6.8 \text { (or SIF } \\
\text { without enzymes) } \\
\text { Enzymes for } \\
\text { Gelatin }\end{array}$ & $\begin{array}{l}\mathrm{pH} 1.2, \mathrm{pH} \\
4.5 \text { and } \mathrm{pH} \\
6.8, \text { no } \\
\text { surfactants. } \\
\text { Enzymes for } \\
\text { Gelatin }\end{array}$ \\
\hline $\begin{array}{l}\text { Media } \\
\text { Temperature }\end{array}$ & $37 \pm 1^{\circ} \mathrm{C}$ & $37 \pm 1^{\circ} \mathrm{C}$ & $37 \pm 1^{\circ} \mathrm{C}$ & $37 \pm 1^{\circ} \mathrm{C}$ & $37 \pm 1^{\circ} \mathrm{C}$ & $37 \pm 1^{\circ} \mathrm{C}$ \\
\hline Medium Volume & $900 \mathrm{~mL}$ & $\begin{array}{l}900 \mathrm{~mL} \text { or } \\
\text { less }\end{array}$ & $\begin{array}{l}900 \mathrm{~mL} \text { or } \\
\text { less }\end{array}$ & $\begin{array}{l}\text { Not } \\
\text { specified* }\end{array}$ & $900 \mathrm{~mL}$ or less & $\begin{array}{l}900 \mathrm{~mL} \text { or } \\
\text { less }\end{array}$ \\
\hline $\begin{array}{l}\text { Sampling } \\
\text { Schedule }\end{array}$ & $\begin{array}{l}10,15,20,30 \\
\& 45 \text { minutes }\end{array}$ & $\begin{array}{l}10,15,20, \\
30,45,60 \\
\text { and } 120 \\
\text { minutes, or } \\
\text { until } \\
\text { asymptote is } \\
\text { reached. }\end{array}$ & $\begin{array}{l}10,15,20 \\
\& 30 \\
\text { minutes }\end{array}$ & $\begin{array}{l}10,15,20 \& \\
30 \text { minutes }\end{array}$ & $\begin{array}{l}10,15,20,30 \& \\
45 \text { minutes }\end{array}$ & $\begin{array}{l}10,15,20,30 \\
\& 45 \text { minutes }\end{array}$ \\
\hline Replicates & 12 units & 12 units & 12 units & 12 units & 12 units & 12 units \\
\hline $\mathbf{F}_{2}$ Criteria & $\begin{array}{l}\mathrm{f} 2 \text { value is } \geq \\
50\end{array}$ & $\begin{array}{l}\mathrm{f} 2 \text { value is } \geq \\
50\end{array}$ & $\begin{array}{l}\mathrm{f} 2 \text { value is } \\
\geq 50\end{array}$ & $\begin{array}{l}\mathrm{f} 2 \text { value is } \geq \\
50\end{array}$ & $\mathrm{f} 2$ value is $\geq 50$ & $\begin{array}{l}\mathrm{f} 2 \text { value is } \geq \\
50\end{array}$ \\
\hline
\end{tabular}

\section{Acceptance Criteria: $(6,8)$}

Not less than $85 \%$ of labelled amount (12 dosage form) are dissolved within $30 \mathrm{~min}$ in each of three buffers $(\mathrm{pH} 1.2, \mathrm{pH} 4.5$ acetate buffer, $\mathrm{pH} 6.8$ phosphate buffer) using the paddle apparatus at $75 \mathrm{rpm}$ or the basket apparatus at $100 \mathrm{rpm}$ \} Proving similarity of dissolution profiles of $\mathrm{T}$ and $\mathrm{R}$ e.g., using f2-test, unless similarity is obvious. 


\section{$F_{2}$ Calculation formula:}

$\mathrm{F}_{2}=50 \times \log \{[1+(1 / \mathrm{n}) \Sigma \mathrm{t}=1 \mathrm{n}(\mathrm{Rt}-\mathrm{Tt}) 2]-0.5 \times 100$, identical "profiles: $\mathrm{F}_{2}=100$, similar profiles":

\section{$\mathrm{F}_{2}$ between 50 and 100}

Two dissolution profiles are considered similar when the $\mathrm{f} 2$ value is $<50$. To allow the use of mean data, the coefficient of variation should not be more than $20 \%$ at the earlier time points (e.g., 10 minutes), and should not be more than $10 \%$ at other time points. Note that when both test and reference products dissolve $85 \%$ or more of the label amount of the drug in \#15 minutes using all three dissolution media recommended above, the profile comparison with an $\mathrm{f} 2$ test is unnecessary

\section{Conclusion}

Dissolution testing is useful tool in providing information on pharmaceutical product quality following certain post-approval changes made to the product, such as changes in formulation, manufacturing process, site of manufacture and the scale-up of the manufacturing process.

The BCS based biowaiver is depends on active absorption from oral dosage forms, adequate release of the active pharmaceutical ingredient (API) from the product. Physico-chemical properties, such as solubility of the API under physiologic conditions, and its permeability through the membranes of the gastrointestinal tract, play important roles in this respect.

Due to the critical nature of these factors, dissolution of a pharmaceutical product in vitro can, in certain instances, be relevant to anticipate the in vivo characteristics/results which sometimes limit the in-vitro testing even though the dissolution profiles are considered important tools to support the bioavailability of a new pharmaceutical product, the bioequivalence of an essentially similar product or variations and facilitate the registration procedure.

\section{Acknowledgements}

We would like to express our sincere gratitude to $\mathrm{Mr}$. Vijay Satapara (CEO of Isazi Pharma \& Techno consultancy Pvt. Limited) for his great support inspiration and guidance during the study.

Financial Disclosure statement: The authors received no specific funding for this work.

\section{Conflict of Interest}

The authors declare that there is no conflict of interest regarding the publication of this article.

\section{References}

1. Multisource (generic) pharmaceutical products: guidelines on registration requirements to establish interchangeability. In: WHO "Biowaiver List": proposal to waive in vivo bioequivalence requirements for WHO Model List of Essential Medicines immediate-release, solid oral dosage forms Annex 12 World Health Organization [Internet]. Geneva: WHO; 2006 [cited 2021 Apr 03]. Available from: https://www.who.int
2. Guidelines on Submission of Documentation for Marketing Authorisation of a Pharmaceutical Product for Human Use [Internet]. Uganda: NDA [cited 2021 Mar 15]. Available from:

https://www.nda.or.ug

3. Annex to Guidelines on Submission of Documentation for Registration of a multisource (Generic) Finished Pharmaceuticals Products [Internet]. Zimbabwe: MCAZ; 2009 Aug [cited 2021 Apr 12]. Available from:

https://www.mcaz.co.zw

4. Shah VP, Rădulescu FS, Miron DS, Yacobi A. Commonality between BCS and TCS. International Journal of Pharmaceutics. [Internet]. 2016 Jul 25 [cited 2021 Apr 11]; 509 (1-2):35-40. Available from:

https://www.sciencedirect.com/science/journal/03785173

5. Guideline for Bioavailability and Bioequivalence [Internet]. Botswana: MOH; 2015 Apr [cited $2021 \mathrm{Mar}$ 31]. Available from: http://www.moh.gov.bw/

6. Guidelines on Therapeutic Equivalence Requirements [Internet]. Tanzania: TFDA; 2015 Jan [cited $2021 \mathrm{Mar}$ 31]. Available from: http://www.tfda.or.tz/

7. Medicines Control Council, Biostudies [Internet]. South Africa: MCAZ; 2015 Jul [cited 2021 Mar 31]. Available from:

http://www.mccza.com/

8. Guidelines-for-registration-of-Human-and-VeterinaryMedicines [Internet]. Kenya: Pharmacy Board Kenya; 2010 [cited 2021 Mar 15]. Available from: http://www.pharmacyboardkenya.org/

9. Sarkar A. Types of Biowaivers: A Discussion. Int J Drug Reg Affairs [Internet]. 2019 Sep 15 [cited 2021 Jun 15];7(3):14-0. Available from: http://ijdra.com/index.php/journal/article/view/329 